\title{
A Nova e Curiosa Relação (1764): escravidão e llustração em Portugal durante as reformas pombalinas
}

The Nova e Curiosa Relação (1764):

Slavery and Enlightenment in

Portugal during the Marquis of

Pombal's Governmental Reforms

\section{Tâmis Parron}

Mestrando em História pela Universidade de São Paulo ${ }^{1}$
Agradeço as leituras muito atenciosas e ricas em comentários dos pareceristas anônimos, de Fernanda Trindade Luciani e de Rafael Marquese, meu orientador, que me apresentou a Nova e Curiosa Relação no curso de graduação de 2003. Também sou grato a Waldomiro Lourenço da Silva Jr., pela indicação de bibliografia sobre direito e escravidão.

\section{Resumo}

0 presente artigo analisa o panfleto anônimo lançado em Portugal no ano de 1764 com o título Nova e Curiosa Relação de hum abuzo emendado, ou evidencias da razão; expostas a favor dos Homens Pretos em hum dialogo entre hum letrado, e hum Mineiro. Pouco apreciada na historiografia, a obra encena retoricamente duas concepções intelectuais distintas da escravidão negra: enquanto uma sintetiza argumentos que circulavam desde o início da época das conquistas, como a maldição de Cam, a influência do sol sobre a cor de pele e o título da guerra justa, a outra qualifica tais visões de condenáveis e antiquadas, propondo novas maneiras de compreender o cativeiro negro. Ao final, o artigo procura entender a Nova e Curiosa Relação como diálogo cultural com medidas pombalinas que ampliavam a concessão dos direitos civis a povos não europeus e faz uma breve comparação das transformações por que passavam as concepções do cativeiro no império português com as que ocorriam no império britânico, realçando diferenças e semelhanças que atuariam poderosamente nas crises institucionais dos respectivos impérios.

\section{Abstract}

This article offers an analysis of an pamphlet that was anonymously published in Portugal, in 1764, under the title Nova e Curiosa Relação de hum abuzo emendado, ou evidencias da razão; expostas a favor dos Homens Pretos em hum dialogo entre hum letrado, e hum Mineiro. This work, not much studied by historians so far, shows two different rhetorically conceived conceptions of black slavery. One of them sums up arguments that had circulated since the Conquest Era, e.g, the Curse of Ham, the sun influence over skin color and the title of just war. The other one dissaproves of such viewpoints as inacceptable and old-fashioned, suggesting new ways of understanding black bondage. Eventually the article tries to relate the Nova e Curiosa Relação to some of the Marquis of Pombal's policies that extended civil rights to non-European peoples, comparing the changing perceptions of black slavery both in the Portugues and British Empires, as well as their effects on the verge of the contitutional crisis of both political unities.

\section{Palavras-chave}

escravidão, lluminismo, identidade nacional

\section{Keywords}

slavery, Enlightenment, national identity 
Sobre a influência do lluminismo, ver MARQUESE, Rafael de Bivar. Feitores do corpo, missionários da mente: senhores, letrados e o controle dos escravos nas Américas, 1660-1860. São Paulo: Cia. das Letras, 2004. p.169-216, e MARQUES, João Pedro. Os sons do silêncio: o Portugal de Oitocentos e a abolição do tráfico de escravos. Lisboa: Instituto de Ciências Sociais, 1999. p.35-88. A respeito da "velha ideologia escravista", ver VAINFAS, Ronaldo. Ideologia e escravidão: os letrados e a sociedade escravista no Brasil colonial. Rio de Janeiro: Vozes, 1986. p.93-124, e SUESS, Paulo. "Introdução" a Etíope resgatado: empenhado, sustentado, corrigido, instruído e libertado. $1^{\mathrm{a}}$ ed., 1758. Rio de Janeiro: Vozes, 1992. p.xviiixxvi.

\section{3}

Sobre Manuel Ribeiro Rocha, os historiadores que o julgaram influenciado pelo lluminismo são AZEVED0, Célia M. Rocha's The Ethiopian Redeemed and the Circulation of Anti-Slavery Ideas. Slavery and Abolition, Londres, vol. 24, n¹, p.101-126, Apr. 2003; COSTA, Emilia Viotti da. Da senzala à colônia. $4^{a}$ ed. São Paulo: Ed. Unesp, 1998. p.391; BETHELL, Leslie. A abolição do tráfico de escravos no Brasil. Trad. port. Rio de Janeiro: Expressão e Cultura/Edusp, 1976. p.19. Para uma visão discordante, vide LARA, Silvia Hunold. Fragmentos setecentistas - escravidão, cultura e poder na América Portuguesa. Tese (Livre Docência em História Social). Instituto de Filosofia e Ciências Humanas, Depto. de História, Universidade Estadual de Campinas, Campinas, 2004. p.164, n.77. Veja também sua introdução "Dilemas de um Letrado setecentista". In: ROCHA, Manoel Ribeiro. Etiope resgatado, emendado, sustentado, corrigido, instruido e libertado. Campinas, Instituto de Filosofia e Ciências Humanas, Universidade Estadual de Campinas, 1991. p.5-25. MARQUESE, Rafael de Bivar. Op.Cit. e MARQUES, João Pedro. Op.Cit., também não encontraram topoi iluministas no tratado de Rocha.

Cf. DAVIS, David Brion. The Problem of Slavery in Western Culture. 1a ed., 1966. Harmondsworth: Penguin Books, 1970. p.495496; LARA, Silvia Hunold. Campos da violência: escravos e senhores na capitania do Rio de Janeiro, 1750-1808. Rio de Janeiro: Paz e Terra, 1988. p.17-18 e p.21-22 e LARA, Silvia Hunold. Fragmentos setecentistas - escravidão, cultura e poder na América Portuguesa. Tese (Livre Docência em História Social). Instituto de Filosofia e Ciências Humanas, Depto. de História, Universidade Estadual de Campinas, Campinas, 2004. p.149; PIMENTEL, Maria do Rosário. Viagem ao fundo das consciências: a escravatura na época moderna. Lisboa: Edições Colibri, 1995. p.253-257; LAHON, Didier. Esclavage et confréries noires au Portugal durant l'Ancien Régime (1441-1830). Tese de Doutorado. Paris, EHESS, 2001, 2 vols. vol. I, p. 300-301. Charles Boxer publicou A Nova e Curiosa Relação em "Um panfleto raro acerca dos abusos da escravidão negra no Brasil", nos Anais do Congresso Comemorativo do Bicentenário da Transferência da Sede do Governo do Brasil da Cidade do Salvador para o Rio de Janeiro. Departamento
A penetração de idéias iluministas no pensamento escravista português é assunto controverso, principalmente no que diz respeito aos escritos produzidos sob a influência do governo pombalino. Para o periodo posterior, a historiografia demonstrou que a criação da Academia Real das Ciências de Lisboa, em 1781, sob o reinado de D. Maria I, abriu espaço para o uso de argumentos ilustrados em reflexões sobre o cativeiro, notadamente nas obras de José da Silva Lisboa, Baltazar da Silva Lisboa, Luiz Antonio de Oliveira Mendes e Antonio Ribeiro dos Santos. Para o anterior, entre o século XV e meados do XVIII, os estudos disponiveis indicam que as obras luso-brasileiras dedicadas à escravidão teriam pertencido a uma "velha ideologia escravista", a qual, em sua última fase, assumiria a forma de um "projeto escravista cristão".2

Como definir, porém, o ideário escravista no reinado de D. José I (1750-1777), quando tiveram lugar profundas reformas econômicas, políticas e culturais baseadas na llustração? De fato, alguns historiadores sugeriram a ocorrência de idéias do racionalismo setecentista no famoso tratado do padre Manuel Ribeiro Rocha, Etíope resgatado, empenhado, sustentado, corrigido, instruido e libertado, lançado em 1758. Entretanto, algumas restrições surgiram, e o debate continua em aberto. ${ }^{3}$

Nesse panorama indefinido, a Nova e Curiosa Relação de hum abuzo emendado, ou evidencias da razão; expostas a favor dos Homens Pretos em hum dialogo entre hum letrado, e hum Mineiro, um panfleto anônimo lançado em 1764, tem recebido pouca apreciação da historiografia. 0 opúsculo, composto em forma de diálogo, expediente muito usado no Setecentos para atacar e defender a instituição do cativeiro, é raro por dramatizar a voz de um Mineiro que recorre a um Letrado para se convencer de que os maus tratamentos dispensados a seu escravo não são injustos. Ele foi encontrado em um sebo de Portugal por Charles Boxer, que o publicou pela primeira vez em 1967. De lá para cá, tem circulado no meio acadêmico e merecido breves considerações, como as de David B. Davis, Silvia H. Lara, Maria do Rosário Pimentel e Didier Lahon. ${ }^{4}$ Porém, a obra ainda não recebeu análise circunstanciada que a utilizasse para esclarecer continuidades e rupturas do "antigo pensamento escravista" sob o impacto direto da llustração em Portugal.

Por "antigo pensamento escravista", no universo português, se entende o conjunto de idéias produzidas pela releitura escolástica da teoria aristotélica sobre a servidão natural e propagadas entre o século XV e meados do XVIII. Nesse quadro conceitual, o cativeiro deixou de ser visto como parte intrínseca da natureza humana, para se tornar fruto da contingência histórica do homem. Admitia-se a escravização de povos não-cristãos desde que eles reconhecessem como origem do cativeiro uma das situações caracterizadoras dos chamados títulos justos: miséria extrema, condenação à morte, nascimento de ventre escravo e guerra justa. Por seu turno, o cativeiro dos africanos, em particular, ainda era justificado com a passagem bíblica em que Noé condena à escravidão o filho Cam e seus descendentes. Finalmente, nesse quadro intelectual, as relações diárias entre senhor e escravo eram arbitradas em conformidade com o ethos da vida cristã, refreandose o potencial descomedimento dos proprietários com os sacramentos, as virtudes teologais e a conduta exemplar. ${ }^{5}$

A influência do lluminismo sobre o pensamento escravista no império português é verificável tanto nos discursos produzidos após a fundação da Academia Real das Ciências de Lisboa (1781) como em documentos polí- 
Nacional de Imprensa, Tomo III, 1967. p.173-186 Neste artigo, as citações serão extraidas da edição fac-similar presente no catálogo AGUILAR, Nelson (org.). Mostra do Descobrimento - negro de corpo e alma - black in body and soul. São Paulo: Associação Brasil 500 anos de Artes Visuais, 2000. p.96-97. Daqui para frente, serão dispensadas as remissões a essa edição.

\section{5}

A expressão "antigo pensamento escravista" está em MARQUES, João Pedro. Os sons do silêncio: o Portugal de Oitocentos e a abolição do tráfico de escravos. Lisboa: Instituto de Ciências Sociais, 1999. p.65-73; os justos títulos e a releitura escolástica de Aristóteles foram analisados por ZERON, Carlos Alberto de Moura Ribeiro. La compagnie de Jésus et l'institution de l'esclavage au Brésil: les justifications d'ordre historique, théologique e juridique et leur intégration par une mémoire historique (XVI-XVIIe). Tese (Doutorado "Histoire et Civilizations"). École des Hautes Études en Sciences Sociales, Paris, 1998, cap. 2. p.196-310; a respeito dos justos títulos desde a tradição romana até a escravização dos africanos, veja-se também ANDRÉS-GALLEGO, José. La esclavitud en la América española. Madri: Ediciones Encuentro, S.A. y Fundación Ignacio Larramendi, 2005. p.26-48; cf. estudo detalhado da maldição de Cam e de suas releituras após o século XV em BRAUDE, Benjamin. The Sons of Noah and the Construction of Ethnic and Geographical identities in the medieval and Early Modern Periods. The William and Mary Quarterly, Williamsburg, 3rd Ser., vol. 54, No. 1, p. 103-142, jan. 1997; acerca das relações senhor-escravo, vide MARQUESE, Rafael de Bivar. Feitores do corpo, missionários da mente: senhores, letrados e o controle dos escravos nas Américas, 1660-1860. São Paulo: Cia. das Letras, 2004. Cap. 1, p.19-83.

6

Cf., respectivamente, MARQUES, João Pedro. Op.Cit., p.35 e MARQUESE, Rafael de Bivar. Op.Cit., cap. 4.

7

Sobre a situação da América portuguesa no cenário mundial, cf. SCHWARTZ, Stuart B. Segredos internos: engenhos e escravos na sociedade colonial, 1550-1835. São Paulo: Cia. das Letras, 1988. p.157-169; FALCON, Francisco Calazans. Pombal e o Brasil. In: TENGARRINHA, José (org.). História de Portugal. Bauru/São Paulo, Edusc/Unesp, 2000, cap. 9. p.149-163. A respeito do ouro, ver crítica contemporânea em ANTONIL, André João. Cultura e opulência do Brasil por suas drogas e minas. Edição fac-similar da 1a ed., 1711. Recife: Imprensa da Universidade Federal de Pernambuco, 1969. p.139 e p.179-181. 0 problema dos comissários volantes foi abordado por MAXWELL, Kenneth. Conflicts and Conspiracies: Brazil and Portugal, 1750-1808. Cambridge: Cambridge University Press, 1973, cap. 1; cf. também seu Marquês de Pombal - Paradoxo do lluminismo. $2^{\text {a }}$ ed. Rio de Janeiro: Paz e Terra, 1997. p.37-51. ticos. Nos discursos acadêmicos, a maior inovação foi a substituição das virtudes teologais pela linguagem laicizada do interesse pessoal. Realmente, esses textos ensinavam que as paixões e os abusos dos proprietários de escravos deviam ser controlados não mais pela temperança cristã, mas sim pela lógica das vantagens materiais e da preservação da propriedade. Já na reação à diplomacia antitráfico da Inglaterra, homens de Estado lusobrasileiros abandonaram as justificativas neo-escolásticas dos justos títulos para a escravização africana, sendo obrigados a sustentar a continuação do tráfico negreiro em termos de mera necessidade econômica. ${ }^{6}$

0 propósito deste artigo consiste em verificar, por meio da Nova e Curiosa Relação, como alguns aspectos da Ilustração podem ter provocado alterações na percepção intelectual do cativeiro no império português antes de 1780. Para tanto, é necessário, em primeiro lugar, estabelecer o sentido da obra conforme o gênero discursivo do diálogo, pois isso permite compreender a finalidade do texto e a lógica subjacente à confecção das personagens. 0 Mineiro surge ali como construto retórico que representa um conjunto de lugares-comuns sobre a percepção intelectual do cativeiro (influência do Sol sobre a cor de pele, lenda de Cam, arbitrio absoluto do senhor), veiculados em obras dos séculos XV, XVI e XVII, mas tidos como inaceitáveis pelo Letrado, quem procura atualizar a maneira de conceber a escravidão africana. Para esta personagem, a lenda camítica e o título da guerra justa já não são impunemente tolerados, e o ethos do senhor cristão, paradigma moral dos textos redigidos até a primeira metade do século XVIII, se transforma no ethos do senhor ilustrado (racional), cristão (caridoso) e civil (obediente às leis pátrias). Em um segundo momento, o artigo procura relacionar o panfleto com algumas medidas do governo pombalino, sobretudo com o alvará que determinou o fim do tráfico negreiro para o Reino (1761), mas também com a extensão da igualdade civil a nativos americanos (1755) e asiáticos (1761) e com a expulsão dos jesuitas (1759). Ao final do texto, essa abordagem, que une ficção e leis, permite discutir em que medida a divulgação das Luzes na metrópole e a expansão do sistema escravista na colônia transformaram as relações identitárias entre os dois lados do Atlântico.

\section{Reformas pombalinas: economia, cultura e sociedade}

No século XVIII, o império português enfrentava situação econômica e geopolítica desfavorável, para não dizer desastrosa, em perspectiva mundial. A produção açucareira da América portuguesa se arrastava por uma crise secular devido à concorrência antilhana - que, simultaneamente, derrubou o preço do açúcar no mercado europeu e encareceu a mão-de-obra escrava disponível na costa da África -, bem como à alta geral dos preços na colônia após a descoberta do ouro mineiro. Paralelamente, o comércio entre o Reino e as capitanias ultramarinas operava nas mãos de agentes de mercadores ingleses (chamados comissários volantes), que vendiam diretamente seus produtos no Brasil e aquinhoavam parte de seus pagamentos em ouro. ${ }^{7}$ Nesse cenário, os ministros de D. José I tentaram restaurar as finanças do império e reaproximar Portugal do universo cultural e social do norte europeu.

$\mathrm{Na}$ esfera da economia colonial, o governo estabeleceu em 1751 a finta - uma demanda antiga dos exploradores -, ao mesmo tempo em que proibiu o seqüestro por dividas dos bens de mineiros proprietários de mais de 30 escravos. No que toca à agricultura, foram montadas Compa- 
Cf. MAXWELL, Kenneth. Conflicts and

Conspiracies: Brazil and Portugal, 1750-1808. Cambridge: Cambridge University Press, 1973 cf. Também, CARREIRA, António. As companhias pombalinas de Grão-Pará e Maranhão e Pernambuco e Paraiba. Editorial Presença: Porto, 1983. Não por acaso, Caio Prado Jr. formulou o quadro interpretativo do período colonial, cujo conceito básico é o sentido da colonização, por meio da leitura de obras compostas no último quartel do século XVIII e no início do seguinte. Entre elas, o anônimo Roteiro do Maranhão a Goiás pela capitania do Piauí parece ter sido particularmente importante para a definição do "sentido" - isto é, que as colônias não existem senão para benefício econômico exclusivo da metrópole e que sua organização social atende apenas à exportação em larga escala de matérias-primas não concorrentes com as já produzidas no Reino. Citado uma quinzena de vezes ao longo do livro para abordar problemas desde os mais particulares (como açougues, pecuária, população mestiça, caminhos etc.) até os mais teóricos (como o "sentido da colonização"), o Roteiro forneceu, nas palavras do próprio Caio Prado Jr., "a mais lúcida sintese da economia brasileira de fins daquele século". Embora delimite cronologicamente a obra no final do XVIII, o autor projeta para os séculos precedentes a idéia ali formulada de que todo o empreendimento colonial português no Brasil não foi senão uma empresa mercantil. Cf. PRADO Jr., Caio. Formação do Brasil Contemporâneo. $3^{\text {a }}$ ed. São Paulo: Editora Brasiliense, 1948. p.14-26 e p.113-128; cf. também, p.127, 156, 181, 186, 190, 194, 198, 227 e 240

9

A este respeito, cf. as Instruçõens para os professores de Gramática Latina, Grega, Hebraica, e de Rhetorica, Ordenadas, e mandadas publicar por El-Rey Nosso Senhor, para o uso das Escolas novamente fundadas nestes Reinos, e seus Domínios. Lisboa: Offc. De Miguel Rodrigues, 1759. nhias Gerais de Comércio - a do Grã-Pará e Maranhão e a de Pernambuco e Paraiba -, para pluralizar os gêneros agrícolas (algodão, arroz e cacau) e impulsionar o abastecimento do trabalho escravo africano. No nivel administrativo, a transferência da capital da colônia para o Rio de Janeiro atendia à vigilância fiscal e militar sobre a zona aurifera, bem como à garantia do fornecimento de mão-de-obra africana para as minas. Até meados do século XVIII, a América portuguesa nunca tinha sido tão colônia de Portugal e, ao mesmo tempo, desfrutado tantas benesses da Coroa. ${ }^{8}$ Como veremos, a Nova e Curiosa Relação partilha com as reformas ilustradas o mesmo projeto doutrinário de aperfeiçoar as práticas sociais do Reino ou das colônias mediante sólidos conhecimentos racionais calcados na llustração.

Afora o universo econômico, a produção cultural portuguesa também sofreu radical transformação, sobretudo em 1759, quando a Companhia de Jesus foi expulsa de todo o império. Nesse mesmo ano, o ensino secundário, antes confiado aos inacianos, ganhou estatutos novos, que deviam emoldurar a imagem moderna do súdito português. Em suas instruções aos recém-admitidos professores, a monarquia idealizava o tipo de aluno que gostaria de formar: cristão, bom súdito e ilustrado. "Terão os Professores também", dizem elas, "o cuidado de inspirar aos Discipulos um grande respeito aos legítimos Superiores, tanto Eclesiásticos como Seculares: Dando-Ihes suavemente a beber, desde que neles principiar a raiar a luz da razão, as saudáveis Máximas do Direito Natural, que estabelecem a união Cristã e a Sociedade Civil; e as indispensáveis obrigações do Homem Cristão, e do Vassalo; e Cidadão". 9 A política pombalina no campo educacional - que levaria à reforma da Universidade de Coimbra, em 1772 - também abriu espaço para a circulação de idéias de filósofos franceses e italianos. Embora a Nova e Curiosa Relação tenha sido lançada antes que a censura permitisse a publicação de 0 Espírito das Leis, seu autor anônimo, inserido nesse clima de gradativa abertura intelectual, provavelmente esteve em contato com o famoso tratado de Montesquieu, como o sugere a semeIhança de argumentos sobre queda da validade dos justos títulos por causa do aperfeiçoamento humano.

Finalmente, o governo português emitiu uma série de medidas para reformar as relações sociais no Reino, na América e na Ásia. De 1755 a 1773, súditos antes despojados de direitos civis elementares foram gradualmente elevados à condição de vassalos europeus, deixando de carregar estigmas juridicamente regulamentados de ascendência étnica e religiosa. Índios americanos, nativos asiáticos, cristãos novos e escravos africanos em Portugal constituiram os grupos humanos explicitamente beneficiados pela inédita inclusão na sociedade civil. Como deve ficar claro ao final deste artigo, a Nova e Curiosa Relação estabelece intimas relações de complementaridade semântica com essas medidas pombalinas.

\section{Diálogo como gênero discursivo}

Talvez seja necessário proceder a uma síntese do modo de imitar próprio do diálogo, para apreender a função de um texto como a Nova e curiosa relação. Segundo Aristóteles, é nas epopéias cantadas por Homero que residem as raizes da tragédia. Se a tragédia era igual ao verso épico na imitação de ações superiores por meio da linguagem, diferia dele ao abandonar a narração em favor da atuação de atores - a performance, em linguagem moderna. Posteriormente, Ésquilo teria sido o primeiro a distri- 
10

ARISTÓTELES. Poética .Trad. port. Lisboa, Guimarães Editores, 1964. cap. III-VI.

11

Cf. PÉCORA, Alcir. Máquina de Gêneros. São Paulo: Edusp, 2001; BURKE, Peter. As Fortunas d'O Cortesão. Trad. port. São Paulo: Unesp, 1997. Poder-se-ia mencionar aqui os Diálogos das grandezas do Brasil (1618); contudo, como o leitor terá percebido, importa menos citar diálogos que falem da colônia do que os consagrados, que vulgarizaram as regras do gênero.

12

LOBO, Francisco Rodrigues. Corte na Aldeia. Lisboa: Editorial Presença, 1992. p.65.

13

VERNEY, Luis António. Verdadeiro método de estudar - cartas sobre retórica e poética. Lisboa: Presença, 1991. p.84-85.

14

Sobre o objetivo da retórica, ver ARISTÓTELES. Retórica. Lisboa: Casa da Moeda, 1998, livro II, 1. A definição do diálogo como meio de formação de juizo se encontra em PÉCORA, Alcir. Op.Cit., p. 97. buir as falas das personagens para dois atores, diminuindo a relevância do coro e aumentando a do diálogo. Foi com tais observações que Aristóteles cingiu os campos da epopéia e da tragédia, dando a ver a origem do diálogo. ${ }^{10}$

Contudo, não foi na tragédia, mas nos escritos de Platão que o gênero adquiriu o que hoje se reconhece propriamente por diálogo em toda sua "autonomia formal". Costuma-se acusar a descendência do gênero nos textos de Cícero (Academica, Orator, Tusculani), nos escritos de Luciano (Diálogo dos Mortos, Charon) e nas prédicas dos Padres da Igreja contra os pagãos. A matriz clássica - Platão, Cícero e Luciano - voltou a despertar emulação na Renascença, como se entrevê na obra máxima de Baltazar Castiglione (/l libro del Cortegiano, 1528) e no famoso diálogo do português Francisco Rodrigues Lobo (Corte na Aldeia, 1619). ${ }^{11}$ Nesta obra em especial, uma personagem justifica por que escolher a forma dialógica para expor a matéria: "uns [relatos históricos ou a História] servem de conservar a memória, os outros [romances de cavalaria], de enganar o entendimento".12 No primeiro, havia ensino sem deleite; no segundo, deleite sem ensino. A única solução do paradoxo do deleite e do ensino era o gênero do diálogo, em que assuntos sérios contrabalançados pela descontração de conversas informais seriam capazes de elevar o entendimento e recrear o espírito.

A preeminência da fala coloquial ou familiar sobre outras confere ao diálogo certos lugares-comuns cujas qualidades devem concorrer com seu estilo chão. Quando a matéria e ocasião não requerem o sublime nem o vil, o altissonante nem o baixo, aí tem lugar o estilo simples, o "modo de falar natural e sem ornamentos, mas com palavras próprias e puras" para "não ser enfadonho das conversações e nas obras que pedem estilo humilde", segundo Verney. 0 oratoriano afirma ainda que por estilo simples se entendem a moderação do uso de figuras, a repetição natural de vocábulos e a cadência natural da fala (tudo presente na Nova e Curiosa Relação); desnudo da "pompa de ornamentos, esse estilo deixa considerar miudamente todos os pensamentos do escritor. Por isso se diz que o estilo simples é o lapis lydius [pedra-de-toque] do juizo".13

Como se vê, o gênero dialógico se irmana bastante da retórica, pois ambos caminham em direção a um juízo sobre alguma matéria ainda indefinida ou a discutir. 0 que está em jogo, em última análise, é a vitória de uma exposição intelectual sobre outra, que perde autoridade no assunto e consente com o vencedor ou, mantendo a postura inicial, sai desacreditada da audiência ou do público leitor. Para ser direto, pode-se falar de um embate intelectual cujas etapas se orientam à formação de um juizo nos leitores. Normativo, o diálogo não pode deixar de instruir. ${ }^{14}$

\section{A Nova e Curiosa Relação}

Os diálogos entram em curso quando há proposição de algum problema. No particular da Nova e Curiosa Relação - composta de duas personagens em Portugal - um Mineiro procura um Letrado para, com seu auxílio, idear o melhor modo de proceder num "negócio de gravíssima importância". A fábula é simples: o Mineiro prometera alforria em dez anos para um cativo obediente, mas mudou de idéia quando percebeu que a esperança de liberdade estimulou o escravo a prestar serviços com mais empenho. Vendo sua sorte mudar, o negro se tornou displicente, a que o senhor reagiu com maus-tratos e ameaças de vendê-lo no Brasil. Em resposta, o cativo entrou para a Irmandade de Nossa Senhora do Rosário, cujos membros 
15

Segundo Bluteau, "letrado" pode significar homem "ciente. Versado nas letras." Mas a entrada também diz que, "com este título [de letrado], se levantaram os Juristas e particularmente os Advogados; por ventura porque das suas letras todos fiam os seus pleitos. Advogado. Ir consultar um letrado sobre alguma matéria litigiosa." É esse sentido ampliado de bacharel a quem se vai tomar conselho em assuntos difíceis, que caracteriza a personagem letrada do opúsculo. R. Vocabulario Portuguez e Latino [letras k, l, m, n]. Lisboa: Pascoal da Sylva, 1716. p.90.

\section{6}

Ver o cumprimento de promessas como um problema da filosofia moral em Cícero. Sobre as Obrigações civis [trad. Miguel Antonio Ciera, 1a ed., 1764]. Rio de Janeiro: Garnier, 1910, I, cap. 7 e III, cap. XVI; ver também MAQUIAVEL, Nicolau. 0 príncipe. Martins Fontes: São Paulo, 2004, cap. XVIII; SKINNER, Quentin. Introduction. In: Machiavelli. The Prince. Cambridge: Cambridge University Press, 1997. p.IX-XXIV.

\section{7}

ARISTÓTELES. Retórica. Lisboa: Casa da Moeda, 1998, livro I, 2. não podiam, por força de lei civil, serem vendidos à colônia. Eis o impasse: agora, o Mineiro quer anular de vez a promessa de alforria e repassar o cativo para o Brasil, pois tem que os negros são inferiores e biblicamente amaldiçoados; ao ouvir seu caso, o Letrado tenta desenredá-lo de tais convicções. ${ }^{15}$ Como se percebe, a obra reencena o antigo problema da filosofia moral de Cícero, retomado no Renascimento, sobre os casos em que se deve cumprir ou romper com a palavra empenhada, para ser justo. ${ }^{16}$

A obra pode ser dividida em duas partes: uma, que glosa assuntos exteriores à matéria, como a inferioridade do negro e a natureza dos castigos dos escravos no Brasil; outra, que refere o episódio particular entre o Mineiro e seu escravo. Na primeira parte, de conteúdo generalizante, a conversação gira em torno das virtudes razõo e paciência. Na segunda, de conteúdo específico, é o conceito consciência (em oposição ao de conveniência pessoal) que rege a composição.

Essa disposição mostra que a peça se constrói como um grande entimema, isto é, um raciocínio efetuado mediante a justaposição de premissas maiores e menores, das quais se extrai uma conclusão. Na primeira parte, as virtudes paciência e razão compõem as premissas maiores e universais do diálogo; na segunda, o comportamento do Mineiro fornece uma conclusão contrária às grandes premissas e é, por isso, fortemente censurado pelo interlocutor. Esse grande entimema se assemelha aos argumentos irrefutáveis, uma vez que o raciocínio caminha da verdade universal (geral) à verdade particular. ${ }^{17}$

\section{Razão versus crença: pecado, origem da pele negra, título da guerra justa}

0 Letrado introduz o conceito paciência quando pede que o Mineiro conte o seu caso, para que pudesse subministrar o melhor conselho: "é precisa paciência a quem lida com moços, e com escravos". 0 interlocutor o talha com um "De vagar, Senhor Doutor" e introduz imediatamente os dois lugares-comuns da primeira parte, a suposta inferioridade inata dos negros e o poder absoluto do senhor na correção e castigo dos escravos:

\footnotetext{
Que seja necessária paciência para lidar com moços, está feito; porque enfim são filhos alheios, e é gente branca como nós. Mas ser necessária paciência para lidar com escravos: não posso ouvir dizer, nem aturar tal; porque enfim são negros: e como custaram a cada um o seu dinheiro, pode-se fazer deles o que quiser.
}

Nessa fala, o que define o cativo não é seu status jurídico especial, mas sim a inferioridade étnica ("são negros") e a condição de mercadoria comum, que, como uma casa ou um objeto de uso pessoal, está submetida à discricionariedade total do proprietário ( "como custaram a cada um o seu dinheiro, pode-se fazer deles o que quiser"). Essas afirmações levam o interlocutor evocar a virtude que conduzirá boa parte da conversa (a razão):

\footnotetext{
V. m. vive muito escandalizado dos pretos, contudo, porém, não há de negar a verdade. [...] há de negar aquilo que for razão? [...] julgo que o mau procedimento de algum seu escravo o tem ofendido de tal maneira, que o obriga a desafogar nesse grande excesso; porém, espero que, deposta toda paixão, V. m. venha a concordar comigo, se acaso entender, e se capacitar de que é verdade o que eu the disser.
}

Na contra-ofensiva, o Mineiro levanta o tópos da gênese camítica do negro. Ele sempre "ouvira dizer" que "nós os brancos somos descendentes 


\section{8}

Ver BRAUDE, Benjamin. The Sons of Noah and the Construction of Ethnic and Geographical identities in the medieval and Early Modern Periods. The William and Mary Quarterly, Williamsburg, 3rd Ser., vol. 54, No. 1, p.103-142. Cf. Também, Bíblia Medieval Portuguesa: histórias d'abreviado Testamento Velho, segundo o Meestre das Historias Scolasticas. Rio de Janeiro: INL, 1958. p.31-32. Em livro lançado em 1705, o inaciano Jorge Benci uniu explicitamente a maldição de Cam - penar no cativeiro - à cor negra da pele. Vendo o pai nu e "escarnecendo desta nudez", Cam teve amaldiçoada "toda a sua descendência, que no sentir de muitos é a mesma geração dos pretos que nos servem; e aprovando Deus esta maldição, foi condenada à escravidão e cativeiro." Cf. BENCl, Jorge. Economia cristã dos senhores no governo dos escravos. São Paulo: Grijalbo, 1977, I, 2, 31. Em que pese tal associação, a crença era bastante aplicada aos ameríndios desde Nóbrega, de forma que se achava bem difundida. Ainda em 1724, Paulo da Silva Nunes, numa "Proposta da Câmara do Pará a S.M. apresentada pelo procurador de Estado", perguntava-se se os nativos descendiam dos judeus deportados pelo rei Hosea da Assíria ou se descendiam de Cam. Cf. BOXER, Charles Ralph. Relações raciais no império colonial português, 1415-1825. Trad. port. Rio de Janeiro: Tempo Brasileiro, 1967. p.130-131.

\section{9}

SANDOVAL, Alonso de. Un Tratado sobre la Esclavitud. Trad. esp. Madrid: Alizanza Editorial, 1987. p.74. Cf. Também, PURCHAS, Samuel. Purchas his Pilgrimage. Londres, 1613: "Some alledge the heat of this Torrid Region, proceeding from the direc beames of the Sunne; And why then should all the West Indies which stretch from the one tropike to the other have no other people?", apud BRAUDE, Benjamin. Op.Cit., p.136.

\section{0}

BLUTEAU, R. Vocabulario Portuguez e Latino [letras k, l, m, n]. Lisboa: Pascoal da Sylva, 1716. p.704-705. de Adão", enquanto "os negros são descendentes de Cain [Cam], que foi negro, e morreu amaldiçoado pelo mesmo Deus, como consta da Escritura." Em seguida, arrisca, ainda com o saber de oitiva, outro argumento para desqualificar os negros: "Já ouvi dizer que a negrura dos pretos procede deles [de eles] nascerem em clima muito quente". Origem pecadora dos negros, influência do clima sobre sua cor de pele. Em que campo intelectual, cabe perguntar, se inserem esses argumentos?

0 episódio biblico de Cam (Gênesis, 9) é bem conhecido. Passado o Dilúvio, Noé desembarcou em terra firme com seus três filhos, Sem, Cam e Jafet, pelos quais "foi povoada toda a terra", vale dizer, dos quais descendeu toda a humanidade. 0 pai, tendo cultivado algumas videiras, embebedou-se de vinho e adormeceu nu em sua tenda. Vendo-o nesse estado, Cam foi ter com os dois irmãos, em vez de ajudá-lo. Ao saberem do caso, Sem e Jafet cobriram as vergonhas do pai andando de costas, sem ver nada. Novamente são, o patriarca irrompeu em ira contra o filho que não o amparou na embriaguez: "Maldito seja Canaã [um dos filhos de Cam], que ele seja o último dos escravos de seus irmãos". Na Idade Média, essa maldição foi apropriada, lida e relida por tradições orais e escritas, designando sempre o "Outro", fossem os judeus, fossem os riquíssimos déspotas orientais. Sua relação com a África não aparece nem mesmo na Baixa Idade Média, como se nota na História d'Abreviado Testamento Velho (uma alterada tradução portuguesa da Scholastica Historia, de Petrus Comestor, século XII), onde se lê apenas que "Chan viu seu padre desnuado nas partes vergonçosas, começou de escarnecer dele e mostrou-o a seus irmãos". Conforme o historiador Benjamin Braude, foi apenas no Portugal do século XV, nomeadamente na Crônica dos feitos notáveis (Gomes Eannes de Azurara), que provavelmente ocorreu a primeira relação entre pele negra, maldição de Cam e condição de escravo. Na Crônica, os servos negros de cavaleiros islâmicos brancos são descritos como frutos da condenação de Cam imposta por Noé. Esse argumento, que Braude afirma ser uma invenção dos tempos modernos, foi encampado pouco a pouco por toda a Europa do Antigo Regime, fosse católica ou protestante. No império português, seus maiores propositores foram os jesuitas, que ainda o empregavam no início do século XVIII. ${ }^{18}$

Por outro lado, a hipótese do calor ou da latitude como causa da cor negra já era freqüentemente refutada no século XVII, não chegando a encontrar a mesma aceitação que a maldição de Cam. 0 viajante inglês Samuel Purchas, por exemplo, desautorizava em 1613 argumentos baseados no tipo de solo ou na altura da latitude, e o jesuíta Alonso de Sandoval, por sua vez, descartava poucos anos depois a hipótese da latitude com o mesmo raciocínio: "si el tiemple lo hiziera o el clima los causara, los Españoles que viven en tierra de negros, casados con Españolas, engendrarán negros: y al contrario, en nuestra Europa los morenos engendrarán blancos; de lo cual nos desengana la experiencia."19

Essa mesma refutação, comuníssima nos séculos XVII e XVIII, é ainda encontrada no verbete "negro" do Vocabulario Portuguez e Latino, de Raphael Bluteau:

Sobre a cor dos negros há entre os naturais grandes contendas. Atribuem alguns esta cor preta à força do Sol nas terras que estes povos habitam; mas debaixo da Zona Tórrida, aonde perpendicularmente arde este Planeta, há homens tão brancos como na Europa; e na Groenlândia, onde pelo espaço de seis meses apenas chegam os raios solares, há homens tão pretos como na Etiópia, segundo escrevem Pererio, trat. de Groenlândia, e outros autores fidedignos. 20 
21

BOULLE, Pierre H. La construction du concept de race dans la France d'ancien régime. Revue Française d'Histoire d'Outre-mer, Paris, t. 89, n. 336-337, p.155-175, $2^{\circ}$ sem. 2002.
BLUTEAU, R. Vocabulario Portuguez e Latino [letras k, l, m, n]. Lisboa: Pascoal da Sylva, 1716. p.704-705. 0 consentimento de Purchas com a maldição de Cam está em DAVIS, David Brion. The Problem of Slavery in Western Culture. $1^{\mathrm{a}}$ ed., 1966. Harmondsworth: Penguin Books, 1970. p.480-493, principalmente 485-486. Cf. Também, SANDOVAL, Alonso de. Un Tratado sobre la Esclavitud. Trad. esp. Madrid: Alizanza Editorial, 1987: "por aver maldecido Noe a su hijo Cham por la desverguenza que uso con el (...) perdio [Cam] la nobleza: y aun la libertad constandole quedar por esclavo el y toda su generacion de los hermanos (...) Y siendo claro por linaje, nacio escuro", p.74-75.
Segundo o historiador Pierre H. Boulle, a atribuição da "negritude" ao sol e à maldição bíblica decorre da idéia de "raça" vigente no Antigo Regime. Entre os séculos XV e XVII, os atributos físicos e morais dos homens não eram considerados hereditários nem imutáveis, de molde que a educação, a influência do clima, a alimentação e até a copulação pareciam influir na formação da criança tanto quanto o sangue. Apenas na virada do XVII os homens começaram a ser catalogáveis em raças, tendência essa que se cristalizou no XVIII, quando atributos físicos e morais passaram a ser considerados fixos e transmissiveis de geração em geração. Para Boulle, a indeterminação de caracteres físicos e morais do homem, nos séculos $X V$, $\mathrm{XVI}$ e XVII, foi fundamental para que a negritude da pele africana se associasse intimamente à idéia de pecado - a negritude era a prova da maldição de Deus. "Entretanto, isso não representava senão um preconceito cultural, e não racial, pois [...] a negritude da pele não é considerada atributo fixo".21

Ora, toda a argumentação do Mineiro insere-se no campo intelectual delimitado por Boulle: o clima (sol) e o pecado (Cam) são os fatores determinantes da cor negra da pele africana. Em nenhum momento se faz referência ao sangue, à hereditariedade e à poligenia. E nem mesmo se usa a palavra "raça" para dizer que o homem preto constitui uma espécie inferior à do homem branco. 0 Mineiro se revela, assim, como que um compósito retoricamente construído de uma antiga mentalidade (dos séculos XV, XVI e XVII) que concilia elementos climáticos, castigo divino e inferioridade moral, argüições muitas vezes já refutadas, para invectivar os "homens pretos", que não seriam tão homens como os brancos. Nesse sentido, a personagem acumula um punhado de "crenças" e "costumes" antigos que apenas servem de anteparo retórico para que o Letrado a emende com argumentos racionais.

Mas que argumentos serão esses? Um deles é tão antigo quanto as próprias crenças, como o que ensina existir branco nascido nos trópicos e negro em zonas temperadas, a fim de desacreditar o determinismo climático. Entretanto, dois soam mais atualizados, pelo menos no universo intelectual português: a forma da refutação do argumento camítico e a crítica à guerra justa como título de escravização.

Se em Samuel Purchas a maldição de Cam parece plausivel e em Sandoval e Benci é sancionada com todas as letras, no panfleto é a Bíblia mesma que não permite tal ilação: "das escrituras", ensina o Letrado, "não consta que alguns deles [filhos de Noé] fosse preto [sic]; logo os pretos não são pretos por serem descendentes de Cain [Cam]". É verdade que, bem antes de 1764, Bluteau rejeitara essa maldição, mas o fez de maneira menos radical. 0 oratoriano não diz que a interpretação camítica contraria o que está escrito na Bíblia, senão apenas que, se a cor negra (e o cativeiro) realmente nascesse do pecado de Cam, então seria preciso achar outros pecadores no texto bíblico para justificar a existência da cor de bronze dos povos brasílicos ou da cor de azeitona dos povos chineses. 22 Não se trata, pois, de réplica a partir da leitura crítica, como no panfleto, mas sim de refutação lógica.

A segunda novidade é a contestação do título de guerra justa, que permitia a escravização de prisioneiros de guerra como forma de poupar suas vidas. Na tradição da filosofia ocidental, John Locke foi o último grande pensador a aceitar abertamente esse título. Depois, filósofos começaram cada vez mais a endossar a tese de que prisioneiros de guerra não podiam ser mortos, extraindo dai a conclusão de que as batalhas não ensejavam a redução ao cativeiro. Sem empregar explicitamente o termo "guerra justa", o barão de Montesquieu professou em 1748 que o "direito das gentes 
23

Cf. MONTESQUIEU, Baron de. O Espirito das Leis, livro XV, cap. II; cf. também. "Argumento e razão da obra, a quem ler", que precede 0 Etiope Resgatado. Os jurisconsultos romanos é que haviam definido a escravização por guerra como parte do direito das gentes; dai a crítica a este implicar censura àqueles. Veja-se, por exemplo, esta passagem do Digesto: "Os servos são, pois, submetidos ao nosso domínio ou pelo direito civil ou pelo direito das gentes: pelo direito civil, se alguém maior de vinte anos deixou-se incorrer numa venda para participar do preço. São nossos servos pelo direito das gentes os que são capturados dos inimigos ou os que nascem das nossas escravas" (D.1.5.5.1) Agradeço a Waldomiro Lourenço da Silva Jr. a indicação desse trecho do Digesto.

\section{4}

Cf. LARA, Silvia Hunold. Legislação sobre escravos africanos na América portuguesa. In: Nuevas Aportaciones a la Historia Juridica de lberoamerica. Madrid: Fundación Histórica Tavera-Digibis-Fundación Hernando de Laramendi, 2000 (Cd-Rom). p.345-346. [isto é, o dos jurisconsultos romanos, que escreveram sobre o direito de escravizar na guerra] quis que os prisioneiros fossem escravos, para que não fossem mortos [...] É falso que, na guerra, seja permitido matar [...] Todo o direito que a guerra pode dar sobre os prisioneiros é controlar de tal modo suas pessoas, que não mais possam causar dano." 0 pensamento é claro: mais civilizados que os romanos, os homens modernos podem promover o bem social (não matando prisioneiros) que aqueles falharam em perfazer. 0 pressuposto da evolução moral da humanidade aparece também em autores do universo português. 0 padre Manuel Ribeiro Rocha lembrou que "antigamente tinham os romanos jus vitae et necis nos escravos" - o tempo, contudo, abrandou os costumes e fez com que Justiniano tivesse ab-rogado "este jus, este abuso, esta desordem e esta excessiva crueldade". Apesar da crítica aos romanos, Rocha não questionou os três justos títulos de escravização por eles formulados - necessidade extrema, delito grave e guerra imparcial: "justos são, por direito natural e das gentes", arrematou o padre, "estes títulos para a escravidão se contrair". 23

A redação do panfleto parece filiar-se em outro campo conceitual. A noção de que o tempo civiliza os homens vem ali, como em Montesquieu, atrelada à censura do princípio da guerra justa. Na esteira do pensador francês, o Letrado discorre que os latinos "reputavam como escravos a todos os prisioneiros de guerra", mas, sugerindo que o tempo civiliza os homens, assevera que "este costume prevaleceu entre algumas Nações da Europa: hoje já este abuso está extinto". Ora, se o cativeiro negro não é mais fruto da condição pecadora de Cam, não provém da inferioridade dos negros nem nasce das guerras justas, então o que o sanciona? 0 Letrado é curto e evasivo: "há outras razões políticas e permitidas" para isso. Realmente, é tão curto o espaço de tempo que separa 0 Etíope Resgatado (1758) da Nova e Curiosa Relação (1764), que talvez os motivos da diferença intelectual entre as obras radiquem na expulsão dos jesuitas e no fim da hegemonia de seu pensamento (calcado na segunda escolástica) a respeito da escravização africana. Talvez outra razão ainda mais forte seja o alvará de 19 de setembro de 1761, que proibiu definitivamente o tráfico negreiro para Portugal. Pela primeira vez no império português desde as conquistas do século $X V$, o comércio de homens era anulado por medida legal, e isso se justificava mediante razões meramente políticas e materiais: do tráfico para Portugal resultavam "excesso e devassidão" contra "as leis e costumes de outras Cortes polidas", bem como ausência de trabalhadores para os domínios coloniais. Como que numa notável inversão, os efeitos materiais e morais do comércio negreiro é que determinavam a legitimidade de sua existência, e não a fonte jurídica dos justos títulos. ${ }^{24}$

Sabe-se que o barão de Montesquieu atribuiu ao clima a necessidade de escravizar negros nas Índias Ocidentais. Como a conversação não menciona o argumento, a resposta parece residir em um equívoco semântico do vocábulo "razão", que, enquanto preceito teórico, igualava o homem negro ao branco, mas que, enquanto motivo prático - razão de Estado -, justificava sua escravização. Realmente, as medidas pombalinas para o fomento da produção colonial principiavam pelo maciço investimento material no sistema escravista, e a necessidade de braços negros para o desenvolvimento dos impérios coloniais era ponto pacífico no mundo português, assim como o era, de resto, no pensamento de Jacques Turgot (1727-1781) e nas primeiras reflexões de Malachy Postlethwayt (c. 1707-1767). Para esses ilustrados escritores de economia política, o Estado aparecia em primeiro 


\section{5}

Cf. DAVIS, David Brion. The Problem of Slavery in Western Culture. 1a ed., 1966. Harmondsworth: Penguin Books, 1970. p.394396, e p.429. Para Montesquieu, há "países em que o calor enerva o corpo e enfraquece tanto a coragem, que os homens só efetuam um dever penoso por temor do castigo: a escravatura, portanto, choca menos a razão...", 0 espírito das leis, livro XV, cap.VII. Embora as refutações do letrado não ponham o cativeiro em questão, Didier Lahon levanta a hipótese de que a obra tenha sido destruida pela censura, para explicar o fato de só lhe terem restado dois exemplares. Dificil dizer se houve ou não destruição programática do panfleto. Pode-se apenas dizer que o título da guerra justa, ali questionado de maneira sutil, continuava a valer para a África no XVIII, como também voltou a ser aplicado contra os índios americanos em 1808, quando a Corte se transferiu para o Rio de Janeiro. Mas não é possivel ser conclusivo a esse respeito. Cf. LAHON, Didier. Esclavage et confréries noires au Portugal durant l'Ancien Régime (1441-1830). Tese de Doutorado. Paris, EHESS, 2001, 2 vols. vol. I, p.300, n. 33. 0 autor se baseou em LÓPEZ, E. Martinez. Tablero de ajedrez: imágenes del negro heroico en la comedia española y en la literatura e iconografia del Brasil esclavista. Paris: Calouste Goulbekian, 1998.

\section{6}

A respeito das relações entre Coroa e universo doméstico, cf. LARA, Silvia Hunold. Campos da violência: escravos e senhores na capitania do Rio de Janeiro, 1750-1808. Rio de Janeiro: Paz e Terra, 1988. p.41 e ss. Sobre o respeito ao princípio da soberania doméstica, ver MARQUESE, Rafael de Bivar. Feitores do corpo, missionários da mente: senhores, letrados e o controle dos escravos nas Américas, 1660-1860. São Paulo: Cia. das Letras, 2004. p.16-80, sobretudo p.3237. Silva H. Lara relatou o caso de duas cartas régias de 1688 que, prescrevendo alienação de escravos para penalizar senhores que dispensassem castigos desumanos, acabaram revogadas menos de um ano depois, provavelmente por pressão de proprietários americanos. Cf. LARA, Silvia Hunold. Fragmentos setecentistas - escravidão, cultura e poder na América Portuguesa. Tese (Livre Docência em História Social). Instituto de Filosofia e Ciências Humanas, Depto. de História, Universidade Estadual de Campinas, Campinas, 2004. p.166-167. lugar quando se falava em escravidão. Como o alvará de 1761, o panfleto parece defender o prosseguimento do tráfico negreiro no mesmo campo conceitual em que serão feitas suas futuras defesas, isto é, sem definilo como um bem moralmente regulável, mas o sustentando por motivos essencialmente econômicos e políticos. ${ }^{25}$

\section{Do barão à Bíblia: a teoria cristã ao lado da razão}

Após seguir Montesquieu e mostrar que a legitimidade do cativeiro passava ao largo de princípios raciais, do pecado original e, por fim, da guerra justa, o panfleto põe em cena o tratamento dos negros no Brasil, assunto que é arrematado com o ensinamento da teoria cristã sobre administração escrava. Nessa passagem, o barão cede lugar à Bíblia.

$\mathrm{Na}$ colônia, repara o Mineiro, os negros são enxovalhados como "bestas", apodados de injúrias e assassinados impunemente. Se os senhores "mataram aos negros", conclui, "eles é que ficaram perdendo o seu dinheiro, e cada um é senhor do que é seu." A frase parece ser uma reformulação de uma das máximas de Moisés: "Se um homem ferir seu escravo ou sua escrava com um bastão, de modo que ele morra sob sua mão, será punido. Se o escravo, porém, sobreviver um dia ou dois, não será punido, porque ele é propriedade do seu senhor" (Êxodo 21, vers. 20). As palavras do patriarca, por sua vez, também foram citadas por Montesquieu, que as reescreveu em termos ainda mais próximos que a Nova e Curiosa Relação: "mas se o escravo sobreviver um ou dois dias, não o será [punido], pois que é seu dinheiro" (O espirito das leis, liv. XV, cap. XVII).

Como seria dada a punição? Assim como o pensador francês atribuiu às leis civis a tarefa de limitar as barbaridades dos senhores, assim também o Letrado, quase rente ao seu texto, diz que as normas do Estado sempre puniriam eventuais crimes, a não ser que eles ficassem acobertados: "Que esses senhores de Engenho matassem aos escravos, não o duvido, antes com facilidade disso me capacito", observa ele evocando as leis civis, "mas que por esses homicídios não tivessem castigo, tal não posso crer; salvo se o crime não foi sabido".

Esse trecho alude, com efeito, às intrincadas relações entre Estado e universo doméstico no mundo escravista. Conforme os desejos dos proprietários, a intervenção da Coroa deveria se dar fora da unidade produtiva, apenas para tocar adiante os elementos de continuidade e estabilidade da produção escravista no "nivel geral": legislação sobre seqüestro de bens, fornecimento do contingente de braços, repressão de revoltas escravas, regulamentação sobre procedimentos com prófugos, organização de aparato humano e material para o sossego público, escoamento de produtos para fora da colônia etc. Dentro da unidade produtiva devia prevalecer o "princípio da soberania doméstica", termo que o historiador Yvan Debbash cunhou para definir a autarquia dominial no governo direto sobre a escravaria - controle e disciplina dos corpos, organização e disposição do trabalho são próprios dos senhores. As ordenações e leis que intervinham nessa esfera encontravam grande resistência, sendo às vezes renegociadas e revogadas pela própria Coroa, outras totalmente ignorada pelos proprietários. ${ }^{26}$

Para intervir na soberania doméstica dos senhores, o Letrado apela então para a "teoria cristã", expressamente anotada por Benci, Antonil e Rocha. Conforme essa "teoria", cativos e proprietários estavam sujeitos a uma lista de obrigações reciprocas: ao senhor competiam sustento material (pão e roupa), instrução espiritual (viabilizar os sacramentos), equilíbrio 
27

0 problema da duração do cativeiro era já tinha sido debatido nos escritos neo-escolásticos dos séculos XVI e XVII. Os jesuitas previam que um indio que se vendesse por fome (sob o título da extrema necessidade) não deveria senão sofrer cativeiro de no máximo 20 anos. Por sua vez, um nativo preso à corda, dizia uma lei real de 1587, permaneceria escravo apenas até ressarcir o senhor. Outra lei de 1611 fixava esse tempo em 10 anos. Em meados do século XVIII, a reflexão sobre o cativeiro perpétuo ganhou novas dimensões, à medida que apareceram vozes críticas à escravidão negra. Em 1755, por exemplo, Francis Hutcheson, que refutava o título da guerra justa, alegou que os escravos teriam direito à liberdade após 12 anos de labor contínuo, e os nascituros não poderiam jamais trabaIhar por mais que 30 anos. Como a escravidão era, para ele, apenas uma forma de compensar gastos com compras e manutenção de cativos, 0 termo de serviço deveria durar até a desoneração do proprietário. Menos contestatório e inserido na segunda escolástica, Manuel R. Rocha deslegitimou o jus emptionis (direito de compra) em favor do jus pignoris (direito de penhor), o qual por sua vez conferia ao cativo o jus redemptionis (direito de redenção ou liberdade) após alguns anos de trabalho. Por fim, Luiz Antonio de Oliveria Mendes chegou a escrever, na primeira versão de sua memória sobre o tráfico negreiro, de 1793, que todos os escravos transportados deviam ter direito à liberdade após 10 anos de serviço, advertindo também que a redução ao cativeiro na África era quase sempre tirânica. Essa e outras posições fortes sobre escravidão foram suprimidas na primeira edição de seu texto, em 1812. Sobre a legislação portuguesa indigenista, cf. THOMAS, Georg. Política indigenista dos portugueses no Brasil, 1500-1640. São Paulo: Edições Loyola, 1982 p.223 e 231. Cf. também. HUTCHESON, F. A System of Moral Philosophy. Vol. II, book II, chap.14. p.77-86 e book III, chap.III. p.199-212. As idéias de Rocha estão em Etiope Resgatado, partes II e VIII; a respeito do manuscrito de Oliveira Mendes, vide LARA, Silvia Hunold. Fragmentos setecentistas - escravidão, cultura e poder na América Portuguesa. Tese (Livre Docência em História Social). Instituto de Filosofia e Ciências Humanas, Depto. de História, Universidade Estadual de Campinas, Campinas, 2004. p.165-167. nos castigos e moderação no quantum de trabalho. Ao escravo, restavam trabalho eficiente e estrita obediência. Desses aspectos, o ponto central no diálogo é a aplicação dos castigos. Convém lembrar que as primeiras críticas veementes ao cativeiro, como as dos Quakers, enfatizaram exatamente os abusos da violência. Virando tópos literário, esses excessos desbragavam as lágrimas do Candido (Voltaire, 1759) ou encarnavam personagens como Oroonoko (Aphra Behn, 1688), o príncipe africano supliciado em Suriname e cuja história foi levada aos palcos quase todos os anos no século XVIII.

No pensamento da segunda escolástica, a paixão, espécie de turbação do sentimento e do espírito, deveria passar pelo crivo da temperança para não se abastardar em sentimentos perversos nem dar ocasião a suplícios sem causa. Trata-se, enfim, da releitura católica da justa medida aristotélica. Daí o Letrado comparar o homem destemperado ao animal selvagem - "Gente pouco temente a Deus! Gente que tem coração de fera!", dando continuidade à tradição cristã sobre o tema, como se vê em Benci (Economia cristã, III, 1, 130) e em Rocha (Etíope resgatado, V, 29). Em sintese, os que se excederam em castigos "pecaram mortalmente". Se o Estado não os pudesse punir, Deus o faria sem perdão.

Esse ponto evidencia como a Nova e Curiosa Relação se encontra numa posição intermediária entre o pensamento escravista cristão e o pensamento influenciado por idéias iluministas. Ao refletir sobre assuntos abstratos - a legitimidade do cativeiro e o pecado de Cam - o Letrado se distanciara do cânone jesuítico. Mas, quando a matéria entrou na esfera da consciência, aí voltou a ter lugar todo o escrúpulo do velho pensamento cristão. Efetivamente, a acepção de interesse material como mecanismo de controle moral dos individuos circularia em Portugal somente com o estabelecimento da Real Academia das Ciências de Lisboa.

Estamos de fato no clímax da primeira metade do opúsculo - aquela dedicada à matéria exterior ao assunto. 0 Mineiro observa então que era difícil tratar bem os escravos quando muitos e preguiçosos. Surpreendentemente, o Letrado responde que faria ainda "pior do que quantos [senhores] lá estão [no Brasil]", sugerindo que o controle dos excessos da escravidão resultava mais realizável em Portugal que nas colônias - de certa maneira, a afirmação complementa o sentido das medidas que o governo pombalino tomou a partir de 1761 para regular e suprimir o cativeiro no Reino, por causa de seus efeitos negativos, mas não no ultramar. Pode-se dizer que a primeira metade do diálogo é arrematada com as seguintes conclusões: na esfera teórica, a justificativa do cativeiro deve ser racional, não havendo relação com negritude, guerra nem maldição; na esfera privada, o senhor deve ser paciente com o escravo e agir sob inspiração da prudência e do amor a Deus. Posto isso, antecipa-se o termo conveniência, que dará rumo à segunda parte do diálogo, sobre o caso particular: "primeiro está o não ofender a Deus, do que o interesse de quantas conveniências podem haver [sic] no mundo."

\section{0 caso particular: respeito ao Estado}

"Senhor Doutor", diz o Mineiro, "o caso é que eu tenho um negro haverá dez para onze anos. No princípio, serviu-me como devia: atendendo eu a isto, prometi-lhe que, se continuasse em me servir bem, no fim de dez anos o daria forro." 0 conselheiro responde então que o outro não fez senão o que era devido. No mais, despertava-Ihe compaixão ver escravos em cativeiro perpétuo. ${ }^{27}$ 
28

LAHON, Didier. Inquisição, pacto com o demônio e magia africana em Lisboa no século XVIII. Topoi, v.5, n.8, p.9-70, jan.jun., 2004, p.19.

29

Inúmeros alvarás sob $\mathrm{D}$. José I reafirmam a irrevogabilidade das decisões do Estado, num franco processo de fortalecimento de seu aparelho burocrático, como o fim da apelação contra decisões dos ministros do governo (1750) ou a livre nomeação régia para os cargos de procurador da Fazenda e do Ultramar (1758), em detrimento do tempo de serviço Cf. FALCON, Francisco. A época pombalina: política econômica e monarquia ilustrada. 2aed. São Paulo: Ática, 1993. p.381-91. Antonio M. Hespanha analisa, nos quadros do lluminismo português, a evolução das fontes do direito e a gradual preeminência das leis nacionais e civis em $A$ história do direito na História social. Lisboa: Horizonte, 1978. p.70-149.

\section{0}

Aqui se pode fazer menção ao parágrafo 4 do título XI do livro $4^{\circ}$ das Ordenações Filipinas, onde se lia que "em favor da liberdade são muitas coisas outorgadas contra as regras gerais [do direito]". Por mais que a propriedade do Mineiro sobre o escravo fosse absoluta, o compromisso moral contraido com a palavra empenhada devia levá-lo a favorecer incondicionalmente a liberdade. Cf. LARA, Silvia Hunold. Legislação sobre escravos africanos na América portuguesa. In: Nuevas Aportaciones a la Historia Juridica de Iberoamerica. Madrid: Fundación Histórica Tavera-Digibis-Fundación Hernando de Laramendi, 2000 (Cd-Rom). p.9899. Agradeço a um dos pareceristas anônimos a sugestão de citar as Ordenações Filipinas.
Em que pese a promessa, o senhor manteve a condição escrava do negro, bem servido que estava de seus obséquios. De resto, havia razões extratextuais que davam verossimilhança à decisão. Como vimos, o alvará de 19 de setembro de 1761 tinha proibido a entrada de novos escravos no Reino português e, assim, restringido o fluxo de oferta daquele tipo de trabalhador. Como o Mineiro possuía o escravo há mais de dez anos e Ihe prometera a liberdade logo depois de comprá-lo, esse compromisso teve lugar antes do alvará de 1761 . Ora, após a decisão régia, o proprietário preferiu cancelar a alforria, mantendo escravo o negro, e, se fosse o caso, vendê-lo imediatamente no Brasil, onde o cativeiro não sofria restrições. Segundo Didier Lahon, era comum negociar cativos do Reino na colônia como forma de castigá-los; porém, após 1761 e 1773 (início da emancipação gradual dos escravos em Portugal), os senhores passaram a vendê-los no Brasil também como forma de "desinvestimento sem perda de capital".28

Na seqüência, o debate reflui muito rápido. Como as grandes premissas já tinham sido armadas contra as convicções do Mineiro, o Letrado enfileira uma série de objeções irrefutáveis, à medida que o proprietário relata seu caso. "Por que eu não possa enganar meu preto?", pergunta-se ele, do contrário "estou eu em igual paralelo com um negro". "Isso foi contra toda a razão", repreende o conselheiro. Ora, o escravista usa o mesmo pressuposto - superioridade do branco - desacreditado durante a primeira parte do diálogo: "V. m. quer que o privilegio de ser branco lhe valha para mentir quanto quiser?", indaga-o o antagonista. "Ora, deixemos esta matéria, vamos ao seu negocio".

0 Mineiro relata que, não encontrando meio de conformar o negro, queria vendê-lo no Brasil, onde ele passaria por maus-tratos da pior espécie. Mas o escravo, entrando na Irmandade de Nossa Senhora do Rosário, estava protegido pela lei que proibia a venda dos irmãos pretos para a colônia. Aqui, a par de todo o campo já explorado - a inferioridade dos negros e os castigos injustos -, dos argumentos racionais contra a parvoíce e dos argumentos cristãos contra os excessos, o Letrado recorre então à premissa que fechará seu discurso: uma lei do Estado jamais poderia ser desrespeitada. "Todo aquele, que não observa as Leis, que os Soberanos põem a seus Vassalos, pecam mortalmente. 0 Privilégio que os Senhores Reis concederão aos pretos dessa Irmandade é uma Lei [...]; logo todo o que violar este Privilégio peca mortalmente". Maldito pela lei divina, reprovado pela razão, o Mineiro também é suscetível de condenação pela lei civil. ${ }^{29}$

Isso permite que, na recapitulação, o homem das luzes faça ver ao adversário todas as razões contrárias a seu comportamento.

É um abuso introduzido entre muitas pessoas imaginarem que os pretos foram nascidos só para serem escravos (...) É injusto o tratamento que muitos senhores dão aos escravos: eles devem ser castigados quando delinqüirem, mas o castigo deve ser proporcionado à culpa (...) V. m. prometeu ao seu preto de o fazer forro, se ele continuasse em o servir bem (...), logo V. m. está obrigado a faze-lo forro. ${ }^{30}$

0 Mineiro ainda tenta convencê-lo de que poderia, sem gravames para a consciência, forrá-lo em quinze ou vinte anos, contra o que expõe o interlocutor parte do repertório das obrigações reciprocas desenvolvidas pela teoria cristã: livrá-lo na velhice importa, antes, livrar-se de sua velhice. Com isso, a segunda parte vem a termo de novo com o tópico da conveniência: 
31

Cf. DAVIS, David Brion. The Problem of Slavery in Western Culture. 1a ed., 1966. Harmondsworth: Penguin Books, 1970. p.363395 e p.438; e SILVA, Luiz Geraldo. Esperança e Liberdade - Interpretações populares da abolição ilustrada. Revista de História, 144, p.116-8, 2001. Segundo Davis, a idéia de progresso se ligou, nos séculos XVIII e XIX, ao conhecimento sucessivo da Lei Natural por meio do uso da razão; à concepção de um cristianismo moralmente evolutivo; à convicção de que os costumes, as leis e as instituições sociais melhoravam em direção do bem universal dos homens; e, posteriormente, à crença em que as instituições democráticas e populares contribuiam para o bem-estar coletivo de uma nação. DAVIS, David Brion, op. cit., p.17 e 46. Na Nova e Curiosa Relação, a idéia de progresso é ligada ao aperfeiçoamento dos costumes sociais e à correção das crenças antigas relativas à escravidão.
"A razão em que me fundo - continua o Letrado - é a verdade; porque eu olho mais para minha consciência, do que para a minha conveniência."

0 dono do escravo não se deixa dobrar, dizendo "cá farei o que entender". Ele dá as costas e vai embora, surpreendendo o leitor moderno, que espera pelo seu convencimento. Contudo, não devia haver espanto, na medida em que o diálogo tem por objetivo necessário a instrução do leitor ou da platéia - e não a redenção da personagem.

\section{Impérios coloniais e escravidão no século XVIII}

É possivel ler a Nova e Curiosa Relação de duas maneiras. Conforme a extensão semântica concedida à personagem do Mineiro, pode-se considerá-la ou como representação dos proprietários de escravos em Portugal ou, por associação metonímica, como representação alegórica das regiões ultramarinas do império português. Nas duas leituras, o panfleto deve ser entendido como uma espécie de diálogo cultural com o alvará pombalino de 19 de setembro de 1761, que, conforme já foi citado, fundamentou a supressão do tráfico negreiro para Portugal no propósito de limitar os "muitos e grandes inconvenientes", bem como "o excesso e devassidão" a ele atinentes. Tanto no texto legal como na obra literária, a escravidão aparece como instituição legítima cujos abusos deviam ser corrigidos. $\mathrm{Na}$ primeira hipótese de leitura, parece que as impropriedades do cativeiro deveriam ser contidas apenas no Reino, como se a obra complementasse os desígnios da lei, regulando o comportamento dos senhores de escravos em Portugal. Na segunda interpretação, o panfleto vem a sugerir que as reformas morais e intelectuais do cativeiro negro podiam se expandir também para o universo colonial - embora se tratasse de um longo e difícil caminho, como o indicou o próprio Letrado ao confessar que faria "pior do que quantos [senhores] lá estão [no Brasil]", se ali vivesse. Em todo o caso, é inequívoca a noção de que a arte deve atuar ao lado do direito na instrução e na correção da sociedade, sugerindo um novo enquadramento intelectual da escravidão negra em perspectiva cristã, civil e ilustrada.

0 procedimento racional que o panfleto recomenda para a reforma dos costumes sociais se deixa definir pelo escrutínio lógico do texto bíblico, pela negação do pecado original camítico, pelo questionamento do título da guerra justa e pelo cumprimento das leis do Estado. 0 embate discursivo ali apresentado, que confronta retoricamente costumes ou crendices com atitudes investigativas e analíticas, se insere nos quadros gerais do lluminismo europeu, segundo o qual as instituições humanas eram consideradas perfectíveis, passiveis de proporcionar cada vez mais o bem-comum racional dos homens. Fosse por meio de um sentimento de benevolência e de utilidade pública, fosse por meio de reformas administrativas e intelectuais, a humanidade parecia estar destinada a ser mais feliz. ${ }^{31}$ Fixado, assim, o sentido da Nova e Curiosa Relação, talvez seja oportuno formular uma pergunta que a remeta para um quadro histórico mais amplo: o que o diálogo e outras medidas pombalinas (por exemplo, o alvará de 19 de setembro de 1761, mas também o de 16 de janeiro de 1773, que libertava gradualmente os escravos em Portugal) nos diz sobre transformações processuais por que passava a instituição do cativeiro ao longo do século XVIII?

Para aquilatar a natureza dessas transformações na Europa e nos impérios coloniais, talvez convenha recuperar o conceito de zonas de violência, desenvolvido pelo historiador Eliga Gould. Conforme o autor, as zonas de violência se localizavam na periferia atlântica dos impérios e eram percebidas 
32

GOULD, Eliga H. Zones of Law, Zones of Violence: The Legal Geography of the British Empire, circa 1772. The William and Mary Quarterly, Williamsburg, v.60, n.3, 2003. Disponivel em: http://www.historycooperative.org/journals/wm/60.3/gould.html. Acesso em: 15 mar. 2005. Sobre insiders e outsiders, cf. ELTIS, David. Europeans and the Rise and Fall of African Slavery in the Americas: An Interpretation. American Historical Review, Bloomington, vol. 98, n.5, p.1399-1423, dec 1993.

33

Sobre o caso dos asiáticos, cf. BOXER, Charles Ralph. Relações raciais no império colonial português, 1415-1825. Trad. port. Rio de Janeiro: Tempo Brasileiro, 1967. p.107. Significativamente, o alvará que os igualava aos súditos europeus estabelecia que "Sua Majestade não distingue seus vassalos pela cor mas por seus méritos". A respeito do fim das distinções entre cristãos novos e velhos, cf. MAXWELL, Kenneth. Marquês de Pombal - Paradoxo do lluminismo. 2a ed. Rio de Janeiro: Paz e Terra, 1997. p.99. 0 Alvará de 1773 consta de LARA, Silvia Hunold. Legislação sobre escravos africanos na América portuguesa. In: Nuevas Aportaciones a la Historia Juridica de lberoamerica. Madrid: Fundación Histórica Tavera-Digibis-Fundación Hernando de Laramendi, 2000 (Cd-Rom). p.359-360 como regiões de além-fronteiras, onde leis diversas, costumes diferentes e necessidades específicas permitiam que os súditos lançassem mão, em nome do empreendimento colonial, de formas de violência inaceitáveis nos territórios europeus, considerados zonas de lei. Entre tais formas, figurariam a escravização de indios e de africanos, algumas técnicas hediondas de guerra e a prática da pirataria. As diferenças entre os dois lados do Atlântico, que teriam surgido no início das Conquistas, persistiram até a formação dos Estados nacionais. Porém, a racionalização administrativa do século $\mathrm{XVIII} \mathrm{e} \mathrm{as} \mathrm{tentativas} \mathrm{de} \mathrm{submeter} \mathrm{as} \mathrm{remotas} \mathrm{regiões} \mathrm{imperiais} \mathrm{ao} \mathrm{direito} \mathrm{da}$ metrópole - o que, nos termos de Hespanha, poderia ser chamado de lenta passagem do paradigma jurisdicionalista (convivio de jurisdições autônomas dentro de uma mesma unidade política) para o estadualista (uniformização das regras legais de um Estado) - reformularam a noção de zona legal dentro da própria Europa, bem como expandiram sua aplicação para determinados aspectos da vida colonial. Esse processo provocou, ainda que muito lenta e ambiguamente, uma inflexão histórica inédita: a expansão gradual dos valores de um contrato social para os homens de todos os lugares do mundo, independentemente da origem, da raça, do credo ou do sistema político. Na prática, tal expansão rarefez o que David Eltis chamou de linha divisória entre outsiders (entre os quais estão os homens passiveis de escravizarem-se) e insiders (os irredutíveis ao cativeiro). ${ }^{32}$

0 alargamento das zonas de lei em detrimento das zonas de violência, por um lado, e a expansão da linha dos insiders sobre a dos outsiders, por outro, tudo isso sugere a ocorrência de mudanças intelectuais importantes tanto nos territórios metropolitanos como na esfera imperial das monarquias européias. No império português, essas transformações se manifestaram na elevação de índios americanos e de nativos asiáticos à condição de súditos da Coroa, respectivamente em 1755 e 1761, como se fossem brancos. Ao mesmo tempo, reformas que expandiram a linha dos insiders no território metropolitano cominaram na abolição da distinção entre cristãos velhos e cristãos novos (1768) e, o mais importante, nas medidas antiescravistas, como o fim do tráfico para o Reino (1761) e o alvará que emancipou ali a escravatura gradualmente (1773). Vale observar que esta última medida qualificava todos os futuros alforriados de "hábeis para todos os ofícios, honras e dignidades, sem a nota distintiva de libertos, que a superstição dos romanos estabeleceu nos seus costumes e que a união cristã e a sociedade civil faz hoje intolerável no meu Reino, como o tem sido em todos os outros da Europa". Nota-se claramente aí a convicção de que, em virtude do progresso civilizador desde os romanos até o presente (o que se lê, de resto, na Nova e Curiosa Relação), deve ocorrer a expansão dos direitos civis a indivíduos outrora relegados à condição de outsiders. A partir de meados do século XVIII, o número de comunidades humanas que podiam tolerar práticas de exclusão civil e a extensão das regiões onde pudessem existir sofreram uma profunda redução conceitual. 33

Contudo, a racionalização administrativa, a unidade jurisdicional e a gradual expansão do contrato social no Século das Luzes ainda reservavam significativas diferenças entre zonas centrais e zonas periféricas nos impérios coloniais. Talvez a mais sensivel delas tenha sido não apenas a manutenção, mas certamente o incremento dos sistemas escravistas na América, que se tornava o lugar por excelência do cativeiro africano, à medida mesma que a escravidão ruía na Europa, identificada como terra da liberdade. Para as colônias, a expansão das zonas de lei significou, na maior parte das vezes, 
34

Vide excelente pesquisa de BROW, Christopher Leslie. Moral Capital - Foundations of British Abolitionism. Chapel Hill: University of North Carolina Press, 2006. p.105-153 e p.209-258; sobre os efeitos da Guerra dos Sete Anos, cf. sintese em BAYLY, C. A. The Birth of the Modern World, 1780-1914-Global Connections and Comparisons. New Deli: Atlantic, 2004. p.93106. Cf. também GREENE, Jack. Liberty, Slavery and British identity in the 18th Century West Indies. Slavery and Abolition, Londres, vol. 21, n¹, p.23-26, April 2000; GREENE, Jack. Empire and identity from the Glorious Revolution to the American Revolution. In: MARSHALL, P.J. (org.). The Eighteenth Century. Oxford: Oxford University Press, 1998. p.225.

35

Embora não fosse regulada por leis, a escravidão não seria instituição ilegal na Inglaterra senão após o Abolition Act de 1833. Ver TEMPERLEY, Howard. British Antislavery, 18331870. Longman, 1972, caps. 1 e 2; DRESCHER, Seymour. Capitalism and Slavery: British Mobilization in Comparative Perspective. Oxford: Oxford University Press, 1987. cap.2. Os argumentos do proprietário de Somerset estão em SWAMINATHAN, Srividhya. Developing the West Indian Proslavery Position after the Somerset Decision. Slavery and Abolition, Londres, vol.24, n³, p.40-60, dec. 2003. arrocho fiscal e perda de antigas autonomias legais. 0 problema é que essas transformações acabaram por colocar em questão a própria legitimidade do cativeiro, como ocorreu exemplarmente no império britânico.

Após a Guerra dos Sete Anos (1756-1763), primeiro conflito europeu a eclodir em escala mundial, atingindo simultaneamente a América, a Ásia e a África, o império britânico passou por drásticas transformações intelectuais e institucionais. Como sugeriu Christopher Leslie Brown, a incorporação abrupta de súditos de diferentes etnias e países à Grã-Bretanha, maior vitoriosa nos conflitos militares, levou a uma grande discussão sobre 0 status civil e sobre o governo dos novos povos. Até então, as tensões entre o investimento material na escravidão e a ideologia da liberdade britânica em formação desde a segunda metade do século XVII - tinha levado muitos súditos a considerar o cativeiro anomalia tolerável e peculiar das colônias, alheia à identidade imperial. Mas, após a Guerra dos Sete Anos, no contexto dos debates sobre os direitos dos povos recém-conquistados, autores britânicos foram além da mera crítica do escravismo e propuseram reformas concretas para revestir os negros de direitos civis. Paralelamente a essa revisão geral de direitos, adveio também uma profunda crise institucional. Quando o parlamento britânico iniciou uma série de operações fiscais para cobrir o espetacular déficit orçamentário acumulado com a guerra, a instituição do cativeiro surgiu como assunto político em um imenso debate público sobre a autoridade do poder legislativo em todo o império. Entre 1763 e 1775, à medida que as discussões escalaram para a revolta e para a independência norte-americana, escritores em favor da Coroa apontaram uma latente contradição no fato de proprietários de escravos reivindicarem maior liberdade política e civil do que gozavam outros súditos ingleses. Em contrapartida, assembléias e panfletistas coloniais vieram a peticionar a proibição do tráfico negreiro, para evidenciar a tirania do governo metropolitano e qualificá-lo de grande responsável moral pela existência do cativeiro na América. Ao fim e ao cabo, simultaneamente, a instituição deixava de ser objeto de crítica para ser objeto de reforma política e se deslocava da reflexão moral sobre abusos privados para a esfera da identidade imperial britânica. Não era mais apenas matéria restrita ao universo senhorial. Era pauta de interesse público. ${ }^{34}$

É nesse contexto que pode ser interpretado o caso de James Somerset, o escravo de Charles Stewart, colono de Boston, que foi considerado livre em decisão judicial de 1772, por ter posto os pés no solo livre da Inglaterra, onde não havia instituições reguladoras do cativeiro. Ideólogos metropolitanos (e também escritores humanitários) capitalizaram imediatamente o evento para reafirmar a autoridade moral da Coroa sobre as renitentes colônias escravistas, que, antes de reivindicar liberdades naturais, deviam passar da condição de zonas de violência para a de zonas civilizadas. No contexto acalorado da crise institucional das colônias, proprietários de escravos vociferaram contra a decisão de 1772 e contra os subseqüentes discursos em favor dos homens negros, dizendo que as leis costumeiras sancionavam a escravidão, com a anuência do governo inglês. ${ }^{35}$

Em perspectiva comparada, a experiência das reformas ilustradas no império português produziu efeitos radicalmente distintos para o futuro da escravidão negra. Como na Inglaterra, discussões sobre o status civil dos súditos estavam na ordem do dia do governo pombalino. Contudo, nota-se uma grande diferença qualitativa na repercussão dos diplomas portugueses de 1761 e de 1773, pois que não resultaram em formação do abolicionismo 
36

Ver LARA, Silvia Hunold. Legislação sobre escravos africanos na América portuguesa. In: Nuevas Aportaciones a la Historia Juridica de lberoamerica. Madrid: Fundación Histórica Tavera-Digibis-Fundación Hernando de Laramendi, 2000 (Cd-Rom). p.345-346.

37

Agradeço a um dos pareceristas anônimos, que me chamou atenção para esses efeitos dos alvarás pombalinos.
Recebido para publicação em julho de 2008 Aprovado em outubro de 2008 no contexto de uma crise institucional profunda. Afinal, o império português não passava por redefinição explícita do estatuto colonial nem por crises fiscais semelhantes à do Stamp Act. Pelo contrário, a racionalização administrativa de D. José I e de Pombal fomentou a produção escravista na América Portuguesa e aproximou a Coroa das elites coloniais. De fato, não havia razão para que o alvará de 1761 se tornasse matéria controversa ou ganhasse um sentido social de ataque político aos colonos. Ao contrário da decisão judicial britânica de 1772, o texto de 1761 previa devolver aos proprietários os cativos que entrassem no Reino à revelia da vontade senhorial: "Não é porém da minha intenção", diz o alvará, "nem que a respeito dos pretos e pretas que já se acham nestes Reinos e a eles vierem dentro dos referidos termos, se inove coisa alguma, com o motivo desta lei; nem que com o pretexto dela desertem dos meus domínios ultramarinos os escravos que neles se acham ou acharem." 36 Nesse sentido, é provável que os diplomas portugueses de 1761 e de 1773 tenham tido efeito, principalmente, nas populações forras e mulatas, que passaram a cobrar igualdade estatutária com brancos, sobretudo dentro dos terços militares. ${ }^{37}$ Isso teria implicações peculiares no momento da crise institucional do império português (1808-1820) e na Constituição brasileira de 1824, que reconheceu a escravidão, mas concedeu cidadania a libertos crioulos.

Em vista disso, pode-se dizer que o autor anônimo da Nova e Curiosa Relação aproveitou o contexto aberto com a decisão de 1761, não para condenar o cativeiro, mas sim para reforçar a moralização da sociedade, instruindo os senhores de escravos a empregar a razão, seguir as leis civis e praticar os preceitos católicos. Ser bom vassalo, bom cristão e bom cidadão não ameaçava a escravidão, apenas a civilizava. Se for admitido que o Mineiro compõe representação alegórica dos espaços coloniais e o Letrado, do Reino, pode-se dizer ainda que o opúsculo recria conceitualmente uma nítida relação hierárquica entre metrópole e colônia, reservando à primeira o papel de arbitrar e civilizar a segunda, identificada como o espaço do saber de oitiva e das práticas nocivas à res publica. Realmente, em contraste com os escritos de Antonil, Benci ou M. R. Rocha, os desentendimentos sobre administração escrava não giram mais em torno de maus e bons cristãos espalhados no novo mundo, mas entre os homens estabelecidos na Europa e aqueles com experiência de vida em lugares violentos.

Por meio da Nova e Curiosa Relação, pode-se aferir, portanto, os impactos que a llustração gerou sobre a compreensão intelectual e sobre a organização institucional do cativeiro no império português. Por um lado, foram gradualmente abandonadas as justificativas de sua reprodução no tempo e no espaço baseadas no direito natural, como o título da guerra justa. Por outro, as diferenças institucionais entre colônia e metrópole se reforçaram com o desmonte gradual da escravidão no Reino. Na crise constitucional do império português (1808-1820), essa espécie de dualidade conceitual entre Portugal civilizado e Brasil bárbaro se manifestará no debate sobre as desvantagens de o Rio de Janeiro, cidade de um pais escravista, sediar uma Coroa de extração européia. Ao mesmo tempo, as medidas pombalinas que estenderam direitos civis a vassalos de extração não-branca se refletirá, de alguma forma, na Constituição brasileira de 1824. Eventualmente, um estudo comparado entre o caso português e o inglês daria a ver bem a influência da escravidão sobre as identidades sociais em formação durante o surgimento das comunidades políticas contemporâneas. 